\title{
METHOD OF CARDIOGRAPHY IN FISHES UNDER AQUARIUM CONDITIONS
}

\section{METODA KARDIOGRAFII U RYB W WARUNKACH AKWARYJNYCH}

\author{
From Department of Fish Physiology \\ Head: Doc. Dr. Remigiusz Węgrzynowicz
}

There was worked out the method or suuyıng heart functional changes in fish in aquarium experiments. In consequence of the operation a rubber balloon was placed in immediate heart neighbourhood and in connection with Marey's tambour the strength and frequency of heart systoles from sinus venosus to bulbus arteriosus was recorded.

Heart functional changes, as a result of the response reactions of fish, are very important in physiological investigations. This concerns especially the reactions connected with exteroception.

On the ground of the method recording changes of heart functions in homothermal animals, there has been worked out the method permitting to record changes of heart work in fish under aquarium conditions. The principle of the biological model depends on recording heart systoles by means of a small air balloon, which in the course of an operation has been placed in the immediate heart vicinity.

Salmo trutta (L.) was the experimental model. 20 minutes before the operation $0,5 \mathrm{ml}$ of "Combelen" was added to the water (to 15 liters of water). After taking the fish out of the water and placing it dorsally, there was made a small incision of the skinand muscles $(1,5 \mathrm{~cm})$ between the epiphysis of the pectoral fins. Ligature-reins were laid on the lips of the wound, to provide facilities for wider lips opening and easier manipulation while inserting the balloon. Then, laying it directly on. the pericardial sac along the long axis, the rubber balloon was inserted through the wound. The balloon was connected with an elastic tube (polyethyl - vinyl). Then, making the best of the ligatures - reins, the wound was closed with knotted sutures (Fig.1). The elastic tube was taken outside, fastened to the skin (with a suture' and connected with Marey's tambour outside the aquarium. The elastic tube transmitting heart systoles was sufficiently long and did not limit locomotory movements of the fish in the aquarium. Changes of frequency and strength of heart systoles were transmitted by air and recorded on a kimograph tape (Fig. 2). 

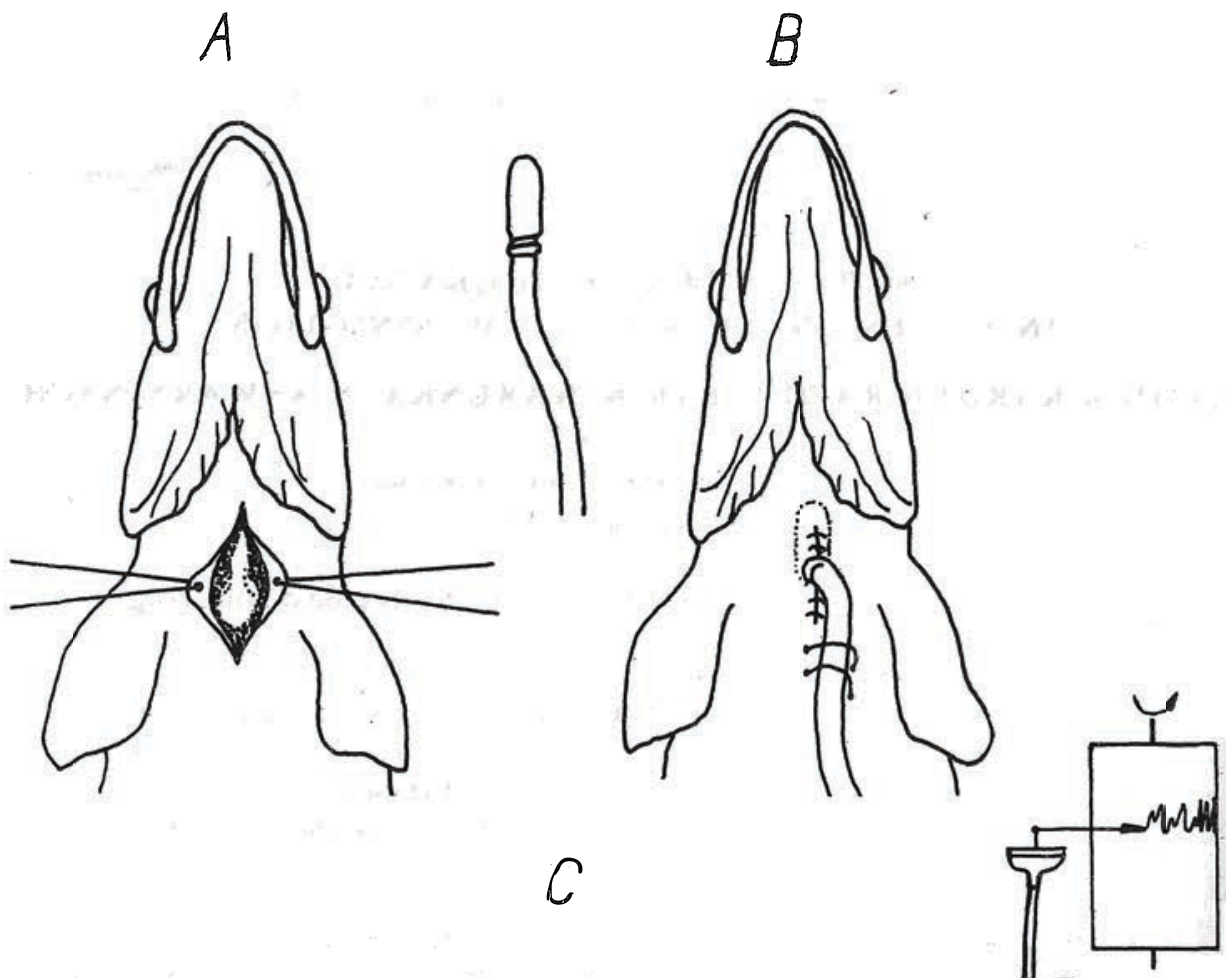

Fig.1. Successive places of preparation of Salmo trutta for experiments. A - skin section and putting of ligatures, B - inserting of the recording balloon, C - cardiography in aquarium

The cardiographic curve obtained by means of the method described above consists of two parts: ascending and descending corresponding to heart systole and diastole. Recesses of successive systole phases : of sinus atrium, ventricle and arterial bulbus are marked on the curve (Fig.3).

By measuring the height of systolic wave, changes in the strength of heart systole can be read out from the obtained record. Systole strength is defined in relative values in the ratio to the initial values.

The altitude of systolic wave before the beginning of the experiment is com pared with the altitude of systolic wave obtained in consequence of the reaction on stimuli applied. 


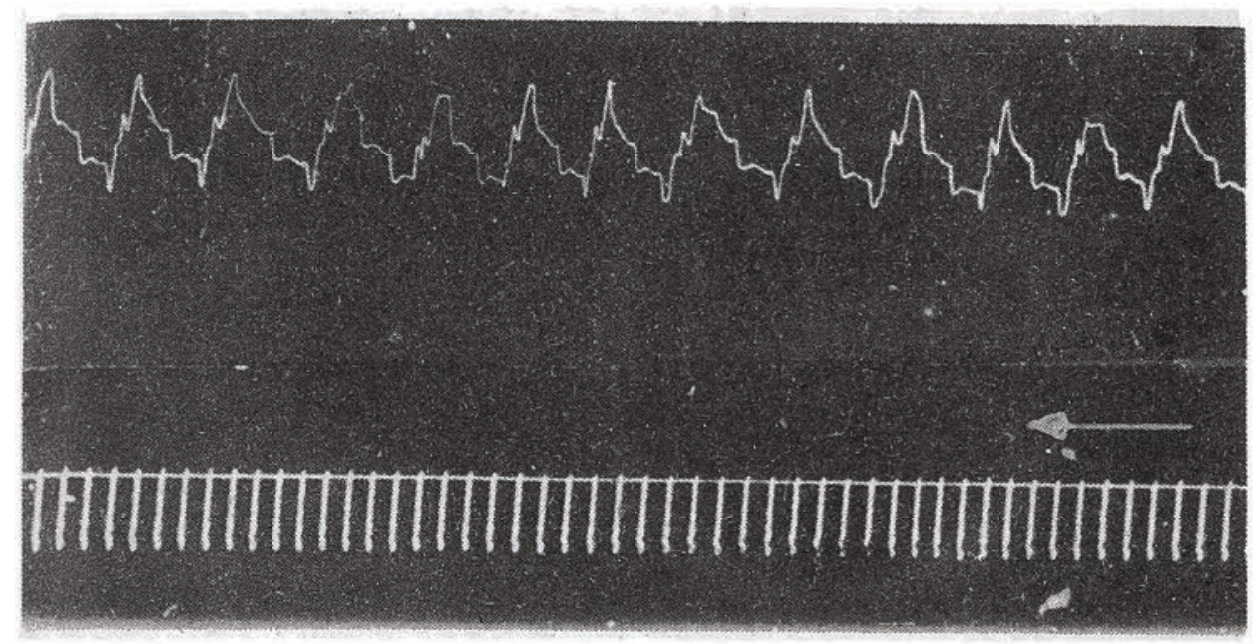

Fig.2. Regular cardiogram of Salmo trutta, bottom: time in sec

Values obtained from the measurements of wave altitude permit to determine in percentages the increase of systolic strength in relation to the initial values. Number of systoles is estimated in time unit. Recesses marked on the cardiographic curve allow to measure changes in particular phases of heart systole (from sinus venosus to bulbus arteriosus).

In the case of sinus-ventricular

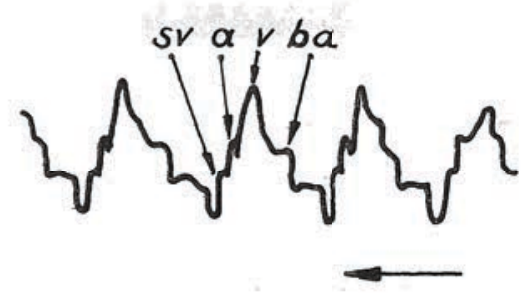

Fig.3. Cardiogram of Salmo trutta, $\mathrm{sv}$ - sinus venosus, a - atrium, v ventriculus, ba-bulbus arteriosus rhythm which often appears in salmon and eel, cardiogram shows a reduced form (Fig.4). On the kimogram there are not any recesses resulting from systoles of atrium which is then at rest.

The method represented above allows to register changes of heart work influenced by impulses acting also upon exteroceptors in aquarium experiments permitting the examined fishes to move.

The obtained kimograms resulting from sinus, atrium, ventricle and bulbus systoles give possibilities of a more accurate analysis of particular heart systole phases.

By means of the above method it is possible to obtain record of heart work continuously during several days, at will changing environmental conditions. Being very simple, the method makes possible serial investigations of that problem. 


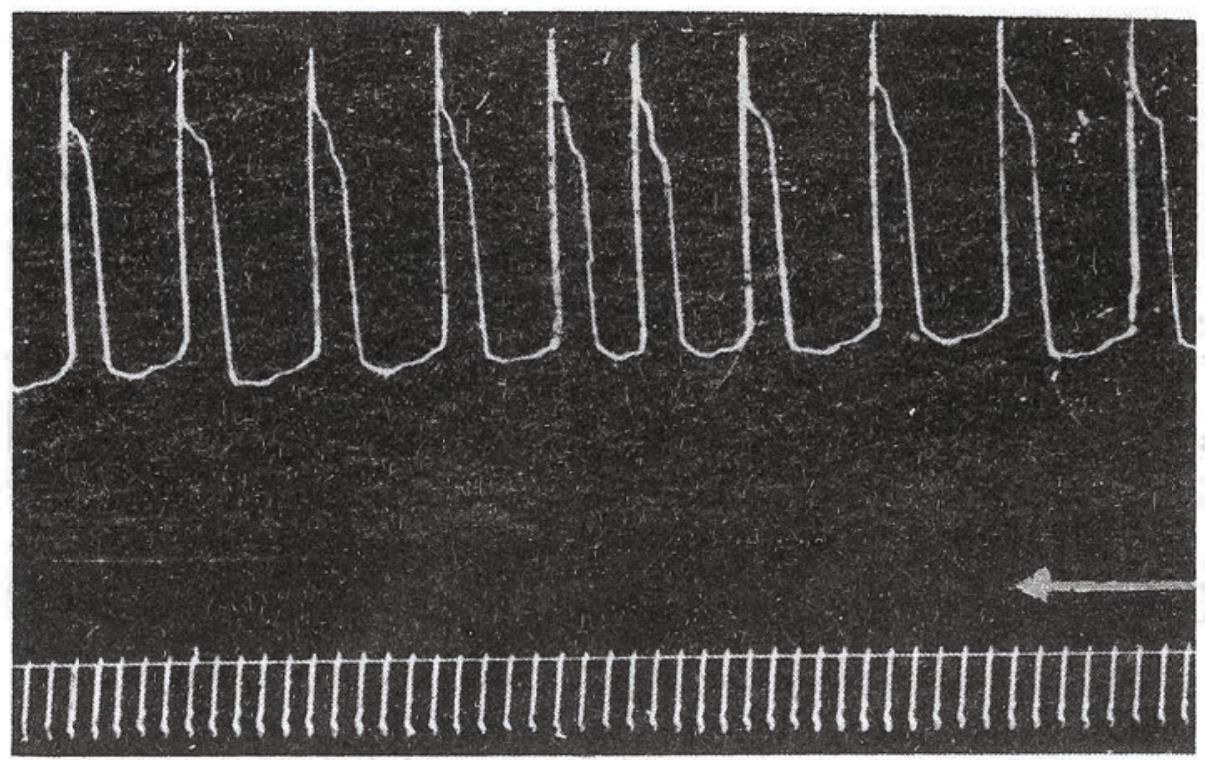

Fig.4. Cardiogram of Salmo trutta in reduced form, bottom: time in sec

\section{REFERENCES}

Węgrzynowicz R., Grünpeter G., D ęb ow y J., 1965: Uleps zona metoda kardiografii w doświadczeniach beznarkotycznych. Acta Physiologica Polonica. XVI, 6, 939.

METODA KARDIOGRAFII U RYB W WARUNKACH AKWARYJNYCH

Streszc.zenie

Opracowano metcdẹ operacyjną uzyskania kardiografii u troci Salmo trutta (L.) w doświadczeniach beznarkotycznych w akwarium. Drogą zabiegu operacyjnego wprowadza się mały, gumowy balonik w okolicę worka osierdziowego. Drogą transmisji powietrznej skurcze serca przekazywane są do bębenka Marey'a i rejestrowane na taśmie kimografu. 
МЕТОД КАРДИОГРАФИИ У РЫБ В АКВАРИУМНЫХ УСЛОВИЯХ

P e 3 ю

Разработано операционный метод по получению кардиограф̆ии у лососьтюйменя (Salmo trutta L.) в безнаркотических исследованиях в аквариум. Путем операции в область сердечной сорочки вводится небольшой резиновый воздушный шарик. Путем воздушной трансмиссии спазмы сердца передаются в барабанчик Марея и регистрируются на киммограф̆ной ленте.

\section{Address :}

Doc.dr Remigiusz Węgrzynowicz

Katedra Fizjologii Ryb WSR

Szczecin, ul.Kazimierza Królewicza 4

Polska-Poland

Received 20. VII. 1968 